\title{
MOTHERS' KNOWLEDGE ABOUT THE REPRODUCTIVE HEALTH NEEDS OF THEIR ADOLESCENT GIRLS
}

\author{
Zaman $\mathrm{B}^{1}$, Shampa RMㄹ, Rahman $\mathrm{MA}^{3}$
}

\begin{abstract}
Introduction: Adolescent is an important segment of life while a child undergoes biological transformation. Objective: The study was conducted to assess the level of knowledge of mothers about reproductive health needs of their adolescent girls.

Methods: This descriptive cross sectional study was conducted on the mothers having adolescent girls. Data was collected by face to face interview with a semi structured questionnaire and analyzed with SPSS. The knowledge of mothers was assessed by Likert scale.

Place of study: The study was conducted at 5 schools of Dhaka city on 118 respondents over a period of four months.
\end{abstract}

Results: It was revealed from the findings that among 118 mothers the mean age of respondents were 40.71 years with standard deviation \pm 3.707 years. Majority $\mathbf{7 0 \%}$ ) of respondents were undergraduate qualified and rest were post graduats. Among the respondents, $64 \%$ of mothers did not want to provide information on reproductive health to their daughters. Seventy two percent of the respondents had average knowledge about puberty. Among the respondents, $47 \%$ had average knowledge regarding adolescent reproductive health problems and $77 \%$ of respondents had average knowledge about safe motherhood. Regarding the complication of unsafe abortion, $73 \%$ had average knowledge and $70 \%$ had average knowledge about consequence of early pregnancy. Fifty seven percent of the respondents had good knowledge about Sexually Transmitted Diseases. Sixty one percent of the respondents had good knowledge regarding the high risk behaviour of the adolescents. Significant statistical association was found between knowledge and education, knowledge and occupation, and knowledge and source of information of reproductive health $(p<0.05)$.

Conclusion: The study findings may be helpful for baseline information and would be beneficial to the policymakers and programme planners to sophisticate further strategy to increase mothers' knowledge about the reproductive health needs of their adolescent girls.
Key words: Knowledge, adolescent, reproductive health needs

\section{Introduction}

World Health Organization (WHO) has defined adolescence as the age group of 10-19 years. The term adolescence literally means to emerge, to achieve identity. One fifth of world population is between 10 and 19 years old. In Bangladesh, adolescents are about 23 percent of the total population ${ }^{1}$. Adolescence is a crossroad in the development of life through which a child gradually walks to reach the maturity of adults ${ }^{2}$. During this important period, a child undergoes biological transition, which is characterized by puberty, related changes in physical appearance and the attainment of reproductive capability ${ }^{3}$.

The United Nations (UN) conference on Population and Development defined reproductive health as 'a state of complete physical, mental and social well being and not merely the absence of diseases or infirmity in all matters relating to the reproductive system and to its function and processes'. The concept of reproductive health (RH) is comprehensive, which includes all health events relating to reproduction in the life cycle of a person. Initially during the year 1970, a special programme was undertaken by WHO to address the issues of 'Human Reproduction' ${ }^{\prime 4}$. Reproductive health needs includes needs for reproductive health care, family planning, HIV/AIDS information, safer sex, unwanted pregnancy, early pregnancy, sexually transmitted diseases (STDs), safe abortion and safe motherhood. For many years, the health of adolescents has been neglected as they are less vulnerable to disease than young children or the very old $^{5}$. Specific sources of information and contraceptive advice are rarely available or accessible to them ${ }^{6}$. Illness relating to sexual and reproductive health may receive inadequate attention as these problems are shrouded in a culture of silence, embarrassment and shame ${ }^{7}$.

In Bangladesh there is poor knowledge of sexual and reproductive health among adolescents. Further more, 'what is known' is often incorrect and derived through communication with friends who are equally

1. Dr Bushra Zaman MBBS, MPH, Lecturer, Department of Community Medicine, Shaheed Monsur Ali Medical College, Uttara, Dhaka, e mailbushra4farhan@yahoo.com; 2. Prof Reshma Mazumder Shampa MBBS, DCM, MPH, FMD, Professor and Head, Department of Community Medicine, Shaheed Monsur Ali Medical College, Uttara, Dhaka; 3. Prof Md Abdur Rahman PhD, Former-Professor, Department of Reproductive and Child Health, National Institute of Preventive and Social Medicine (NIPSOM), Mohakhali, Dhaka-1212. 
unknowledgeable ${ }^{8-11}$. The government of Bangladesh has officially adopted the International Conference on Population and Developement (ICPD) definition of RH and develops a comprehensive plan of action in the light of the Conference recommendations.

In this study an attempt was made to identify the mothers' knowledge about the reproductive health needs of their adolescent girls with a view that further intervention program could be taken, in broader perspective.

\section{Material and Methods}

This was a cross sectional descriptive type of study. The study population was the mothers having adolescent girls of 12-18 years of age. The respondents were selected purposively according to the researcher's convenience. The sample size was 118. The study sites were 5 schools of Dhaka city (Uttara High School, Rajuk Uttara Model School \& College, Shahid Bir Uttam Lt Anowar School \& College, Viquarunnessa Noon School \& College and Savar Cantonment Public School \& College).The schools were selected purposively. The study population was interviewed through a pre-tested questionnaire. The data were collected by face to face interview of the respondents. The respondents' knowledge was graded on the basis of weighted markings for 10 related questions pertaining to mothers' knowledge about the reproductive health needs of their adolescent girls. On the basis of the number of correct answer, each question was weighted with marks 5. Scores of each question was graded according to Likert's scale. The study was conducted for a period of 4 months from March to June, 2008. Data were analyzed by computer using software SPSS.

\section{Results}

It was revealed that out of 118 respondents the mean age of respondents was $40.71 \pm 3.707$ years. Of the total population 96.6\% were Muslim and only 3.3\% were Non-muslim. Among the mothers' $69.4 \%$ were under graduate and 30.5\% were post-graduate qualified. About eighty two percent of the respondents were living in single family. Majority of mother $(60.2 \%)$ had 2 children. Among the mothers' $61.9 \%$ were having only one adolescent girls. The main source of information regarding the reproductive health needs were doctors and mass media as stated. Among the respondents, $74.6 \%$ were housewives and $25.5 \%$ were service holders. Their average monthly income was Tk $37076 \pm 100$ (Table1). Among the respondents $63.6 \%$ didn't want to and $36.4 \%$ wanted to provide information on $\mathrm{RH}$ to their daughters. $76.3 \%$ of the respondents provided information to their adolescent girls about menstruation before menarche and $23.7 \%$ of respondents did not.
Table-I: Socio-Demographic characteristics of the respondents.

\begin{tabular}{|l|l|}
\hline Characteristics & Findings \\
\hline Age & $40.71 \pm 3.707$ years \\
\hline Religion & $\begin{array}{l}\text { Islam-96.6\%, Hindu-2.5\%, } \\
\text { Buddhist-0.8\% }\end{array}$ \\
\hline Education & $\begin{array}{l}\text { SSC-23.7\%, HSC-16.9\%, } \\
\text { Degree-28.8\%, Masters-30.5\% }\end{array}$ \\
\hline Occupation & $\begin{array}{l}\text { Housewife- } 74.6 \% \text {, Private } \\
\text { service }-13.6 \%, \text { Government } \\
\text { service- } 10.2 \%, \text { Others- } 1.7 \%\end{array}$ \\
\hline Monthly income & TK.37076.27 \pm 12812.36 \\
\hline
\end{tabular}

Table-II: Distribution of respondents by their source of information $(n=118)$.

\begin{tabular}{|l|c|c|}
\hline Source & Frequency & Percent \\
\hline Radio and TV & 21 & 17.8 \\
\hline Friend & 04 & 03.4 \\
\hline Book and magazine & 14 & 11.9 \\
\hline Doctor & 48 & 40.7 \\
\hline Relative and neighbour & 12 & 10.2 \\
\hline Other health worker & 19 & 16.1 \\
\hline
\end{tabular}

Table-III: Distribution of respondents by their knowledge regarding puberty $(n=118)$.

\begin{tabular}{|l|c|c|}
\hline Level of knowledge & Frequency & Percent \\
\hline Poor knowledge & 11 & 09.3 \\
\hline Average knowledge & 85 & 72.0 \\
\hline Good knowledge & 22 & 18.6 \\
\hline
\end{tabular}

Table-IV: Distribution of respondents by their knowledge regarding ARH problems $(n=118)$.

\begin{tabular}{|l|c|c|}
\hline Level of knowledge & Frequency & Percent \\
\hline Poor knowledge & 08 & 06.8 \\
\hline Average knowledge & 55 & 46.6 \\
\hline Good knowledge & 40 & 33.9 \\
\hline Excellent & 15 & 12.7 \\
\hline
\end{tabular}

Table-V: Distribution of respondents by their knowledge regarding safe motherhood $(n=118)$.

\begin{tabular}{|l|c|c|}
\hline Level of knowledge & Frequency & Percent \\
\hline Poor knowledge & 13 & 11.0 \\
\cline { 2 - 3 } Average knowledge & 91 & 77.1 \\
\hline Good knowledge & 12 & 10.2 \\
\hline Excellent & 02 & 01.7 \\
\hline
\end{tabular}

Table-VI: Distribution of respondents by their knowledge about complication of unsafe abortion $(\mathrm{n}=118)$.

\begin{tabular}{|l|c|c|}
\hline \multicolumn{1}{|c|}{ Level of knowledge } & Frequency & Percent \\
\hline Poor knowledge & 02 & 01.7 \\
\hline Average knowledge & 88 & 72.9 \\
\hline Good knowledge & 23 & 19.5 \\
\hline Excellent & 07 & 05.9 \\
\hline
\end{tabular}


Table-VII: Distribution of respondents by their knowledge regarding the consequence of early pregnancy $(\mathrm{n}=118)$.

\begin{tabular}{|l|c|c|}
\hline Level of knowledge & Frequency & Percent \\
\hline Poor knowledge & 06 & 05.1 \\
\hline Average knowledge & 82 & 69.5 \\
\hline Good knowledge & 22 & 18.6 \\
\hline Excellent & 08 & 06.8 \\
\hline
\end{tabular}

Table-VIII: Distribution of respondents by their knowledge about STDs ( $\mathrm{n}=118)$.

\begin{tabular}{|l|c|c|}
\hline Level of knowledge & Frequency & Percent \\
\hline Poor knowledge & 18 & 15.3 \\
\hline Average knowledge & 32 & 27.1 \\
\hline Good knowledge & 67 & 56.8 \\
\hline Excellent & 01 & 00.8 \\
\hline
\end{tabular}

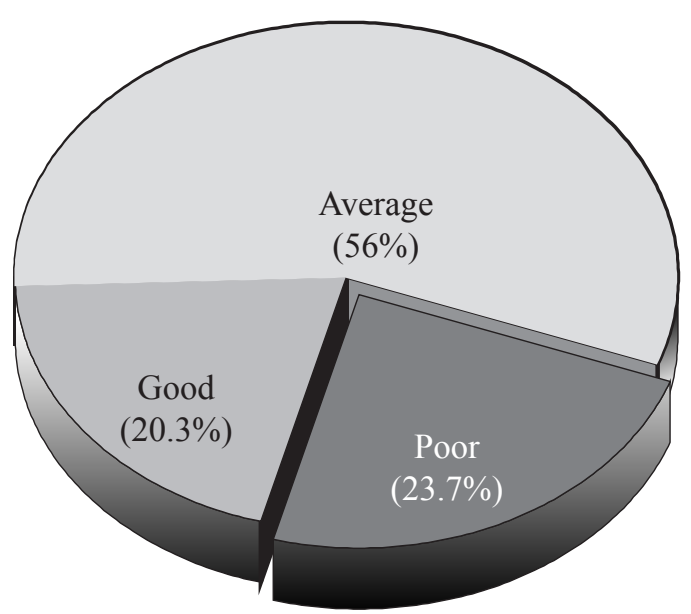

Fig-1: Distribution of respondents regarding the knowledge of RH needs of their adolescent girls.

Table-IX: Distribution of respondents by their knowledge regarding the high risk behaviour of adolescents $(\mathrm{n}=118)$.

\begin{tabular}{|l|c|c|}
\hline Level of knowledge & Frequency & Percent \\
\hline Poor knowledge & 30 & 25.4 \\
\hline Average knowledge & 15 & 12.7 \\
\hline Good knowledge & 72 & 61.0 \\
\hline Excellent & 01 & 00.8 \\
\hline
\end{tabular}

It has been found that that $61 \%$ of respondents had good knowledge, $25.4 \%$ had poor knowledge, $12.7 \%$ had average knowledge and only $0.8 \%$ had excellent knowledge regarding the high risk behaviour of adolescents (Table-IX). Among the respondent it has been revealed that relationship between the level of knowledge with education, occupation and source of information are statistically significant (Table-X).
Table-X: Level of knowledge of respondents in relation to their characteristics $(n=118)$.

\begin{tabular}{|c|c|c|c|c|c|c|}
\hline \multirow{3}{*}{ Characteristic } & \multicolumn{4}{|c|}{ Knowledge } & \multirow{3}{*}{$\begin{array}{l}\text { Total } \\
\mathrm{n}=118\end{array}$} & \multirow{3}{*}{$\begin{array}{l}\text { Test of } \\
\text { significance }\end{array}$} \\
\hline & \multicolumn{2}{|c|}{ Poor } & \multicolumn{2}{|c|}{ Good } & & \\
\hline & No & $\%$ & No & $\%$ & & \\
\hline $\begin{array}{l}\text { Education: } \\
\text { Graduate } \\
\text { Post-graduate }\end{array}$ & $\begin{array}{l}23 \\
05\end{array}$ & $\begin{array}{l}47.9 \\
07.1\end{array}$ & $\begin{array}{l}25 \\
65\end{array}$ & $\begin{array}{l}52.1 \\
92.9\end{array}$ & $\begin{array}{l}48 \\
70\end{array}$ & $\begin{array}{l}x^{2}=26.157 \\
p<0.001\end{array}$ \\
\hline $\begin{array}{l}\text { Occupation: } \\
\text { House wife } \\
\text { Service holder }\end{array}$ & $\begin{array}{l}27 \\
01\end{array}$ & $\begin{array}{l}30.7 \\
03.3\end{array}$ & $\begin{array}{l}61 \\
29\end{array}$ & $\begin{array}{l}69.3 \\
96.7\end{array}$ & $\begin{array}{l}88 \\
30\end{array}$ & $\begin{array}{l}x^{2}=9.246 \\
p<0.001\end{array}$ \\
\hline $\begin{array}{l}\text { Information: } \\
\text { Health personnel } \\
\text { Media }\end{array}$ & $\begin{array}{l}08 \\
20\end{array}$ & $\begin{array}{l}14.8 \\
31.3\end{array}$ & $\begin{array}{l}46 \\
44\end{array}$ & $\begin{array}{l}85.2 \\
68.8\end{array}$ & $\begin{array}{l}54 \\
64\end{array}$ & $\begin{array}{l}x^{2}=4.371 \\
p<0.02\end{array}$ \\
\hline
\end{tabular}

\section{Discussion}

This cross sectional study was carried out with the objective of assessing the level of mothers' knowledge about the reproductive health needs of their adolescent girls. The study was conducted in purposively selected schools of Dhaka city so the result may not represent the total population. Majority of the respondents (44.9\%) were between the ages of 41-45 years. The mean age of the mother was 40.71 years. Among the mothers' $69.4 \%$ were undergraduate and $30.5 \%$ were post-graduates.

In Bangladesh, very little is known about the RH needs of adolescents. Adolescents do not have access to correct information about reproduction, fertility and fertility regulation and their $\mathrm{RH}$ needs are largely ignored by current programme activities ${ }^{12,13}$. Bangladesh Rural Advancement Committee (BRAC) study mentioned that mothers, sister-in-laws and friends were the sources of information about menstruation for most of the adolescents ${ }^{9}$. Gupta Sadhna conducted a study and the results showed that, the major source of information for adolescent physical change and menstrual problems was mother or elder relative, followed by books, television and teachers ${ }^{14}$. Coff $\mathrm{E}$ noted that mother was an important source of information but she was often unable to meet the queries ${ }^{15}$. In this study the main source of information regarding the reproductive health needs were doctors and mass media as stated. Nahar et al carried out a study among adolescents and found that adolescent girls usually did not know about menstruation before they experience that ${ }^{8}$. Only 34\% knew about it and they received knowledge from experienced girl friends who already had experienced it or from elder sisters or cousins. Some of them knew about it by observing the behaviors of older people during their menstrual period.

Anand Tamang conducted a study in Buglung and Lalitpur district of Nepal reported that, $73.3 \%$ of adolescent told that they learnt about menstruation before menarche and their sources of information were 
mothers $(72 \%)$, friends $(49 \%)$ and sisters $(44 \%)^{16}$. In the reported study correlates with these findings as shown by the fact that $76.3 \%$ mother informed their adolescent girls about menstruation before menarche and $23.7 \%$ did not. About $95 \%$ of adolescent girls discussed with their mother regarding any menstrual or reproductive health problems.

Among mothers, $63.6 \%$ did not want to provide information and $36.4 \%$ wanted to inform their adolescent girls regarding RH needs. Only $34.7 \%$ mothers had good knowledge on RH and $65.3 \%$ of respondent had average knowledge. About puberty $72 \%$ had average knowledge, $9.3 \%$ had poor knowledge and only $18.6 \%$ had good knowledge. Regarding the $\mathrm{RH}$ problems of female during adolescent period $46.6 \%$ of respondent had average knowledge, $33.9 \%$ had good knowledge, 12.75 had excellent knowledge and $6.8 \%$ had poor knowledge. Among the mothers $77.1 \%$ had average knowledge and only $1.7 \%$ had excellent knowledge regarding safe motherhood. In Bangladesh, 14\% of all obstetric deaths are due to abortion complications ${ }^{17}$. The health consequences of abortion are particularly acute for adolescents. Unmarried adolescents are considerably more likely than older women to delay seeking abortion $^{18}$. This study showed that $72.9 \%$ had average knowledge on the complication of unsafe abortion and only $1.7 \%$ had poor knowledge on that subject. Only $22 \%$ of respondents had good knowledge about consequence of early pregnancy. The relationship between education with knowledge, occupation with knowledge and source of information with knowledge were statistically significant $(\mathrm{p}<0.05)$.

Ismat B et al observed that adolescents constitute onefourth of the population of Bangladesh ${ }^{19}$. The effects of globalization, rising age at marriage, rapid urbanization and greater opportunities for socialization have heightened the risk of sexually transmitted infections (STIs), HIV/AIDS and unwanted pregnancy. This study revealed that $56.8 \%$ of mothers had good knowledge about STDs and $27.1 \%$ of mothers had average knowledge. Knowledge about the high risk behaviour of adolescents showed that $61 \%$ of respondent had good knowledge and $12.7 \%$ of respondents had average knowledge. Regarding STDs knowledge of mothers was quite good because of continuous mass coverage in TV, Radio and News papers for the last few years and also due to several government and non-government organization activities.

\section{Conclusion}

From this study it revealed that mothers' knowledge about the reproductive health needs of their adolescent girls were not satisfactory. Though majority of mothers were educated, but most of them were not knowledgeable regarding ARH needs. In reported society, parents hesitate to discussing such matters with their children which could be achieved by incorporating family life education (FLE) or sex education in school curricula. The unmet need of adolescents for reproductive health information and services is huge and diverse both in terms of quality as well as quantity.

\section{Refernces}

1. Hossain MS. Status of adolescent girls in Bangladesh, 1995. Dhaka: Bangladesh Bureau of Statistics; 1996.

2. Haider SJ, Saleh SN, Kamal N, Grey A. Study of Adolescent: Dynamics of perception, attitude, knowledge and use of reproductive health care.1st ed. Dhaka: Population Council of Bangladesh; 1997. p. 17-21.

3. Agampodi SB, Agampodi TC, Piyaseeli. Adolescents' perception of Reproductive health care services in Sri Lanka. Bio Med Central Health Service Research 2008; 98: 1-8.

4. World Health Organization. Adolescence- the critical phase, the challenges and the potential. Geneva: World Health organization (WHO); 1997.

5. World health Organization. The Health of Young People: A challenge and a promise. Geneva: World health Organization; 1993; 21: 39-46.

6. World health Organization,1989. The reproductive health of Adolescents: a strategy for action. A Joint WHO/UNFPA/UNICEF statement. Geneva: World Health organization; 1989.

7. Barua A; Kurz K. Reproductive health-Seeking by married Adolescent girls, India. Reproductive Health Matters 2001; 9(11): 53-62.

8. Nahar Q, Tunon I, Houvras R, Gazi M, Reza, Huq NL, Khuda B. Reproductive health needs of adolescents in Bangladesh: a study report (working paper). Dhaka: International Center for Diarrhoeal Disease Research(ICDDRB); 1999: 130.

9. Ali A, Mahmud SN, Karim F, Chowdhury. Knowledge and Practice of NEPEAG graduates regarding menstruation. Dhaka: Bangladesh Rural Advancement Committee; 1996.

10. Ahmed S. Behavioral aspects of reproductive health among poor adolescent female in Dhaka, Banglades (Thesis). London: London School of Hygiene and Tropical Medicine, 1991.

11. Bangladesh Bureau of Education Information and statistics. 'National Educational Survey' (post primary), 1999 (Final report 2001). Dhaka: Ministry of Education, Government of the People's Republic of Bangladesh; 2002

12. Nahar Q, Amin S, Suttan R, et al. Strategies to meet the health needs of adolescents: A review. Dhaka Operation Research Project. Dhaka: International Centre for Diarrhoeal Disease Research, Bangladesh(ICDDR,B); 1999: Special publication 91.

13. Hossain MS, Bhuiya I, Rob AKU, Anam R. Directory of organizations working with adolescent/youths. Dhaka: Population Council; 1998.

14. Shdhna G, Achala S. Awareness about reproductive and adolescent changes among school girls of different socio-economic status. J Obstet Gynecol India 2006; 56(4): 324-328.

15. Coff E, Rierdan J. Preparing girls for menstruation, recommendations from adolescent girls. Adolescence 1995; 30: 795-811. 16. Tamang A, Adhikari R and Tamang J. Adolescent Girls Initiate for their Reproductive Health Phase-II. Nepal: Centre for Development and Population Activities (CEDPA); 2003. p.10-65.

17. Working Paper. Situation Assessment and Analysis of Children and Women in Bangladesh. Dhaka: Government of Bangladesh and UNICEF; 2000.

18. Ministry of Health and Family Welfare (MOHFW). Adolescent's Health and Development Issues and Strategies: Empowering Adolescent Girls for Sustainable Human Development, Bangladesh Country Report. Proceeding of South Asia Conference on Adolescents 21-23 July, 1998. India: Delhi UNFPA; 1998.

19. Ismat B, Rob U, Chowdhury AH, Rahman L, Haque N. Improving Adolescent Reproductive Health in Bangladesh. Population Council 2004: 5-72. 